J. Lake Sci.(湖泊科学), 2009, 21(1): 10-20

http://www.jlakes.org. E-mail: jlakes@niglas.ac.cn

(C2009 by Journal of Lake Sciences

\title{
水工工程对长江下游渔业的胁迫与补偿*
}

\author{
施炜纲 ${ }^{1,2,3}$, 张敏莹 ${ }^{1,2,3}$, 刘 凯 ${ }^{1,2,3}$, 徐东坡 ${ }^{1,2,3}$, 段金荣 $1,2,3$ \\ (1: 中国水产科学研究院内陆渔业环境与资源重点开放实验室, 无锡 214081) \\ (2: 中国水产科学研究院淡水渔业研究中心, 无锡 214081) \\ (3: 长江下游渔业资源监测站, 无锡 214081)
}

摘 要: 长江下游及河口区鱼类物种丰富, 特有性高. 能构成渔汛的经济品种均集中在该江段, 其可捕的经济鱼类品种及渔获量 为全江之首. 该水域鱼类区系复杂, 是长江物种多样性最为丰富的区域之一. 随长江干流上水工建筑的大量建造, 江湖被隔绝, 洄游通道被阻断, 海水的人侵、生境的破碎、水文条件的改变等导致了渔业生态功能的削弱，对下游鱼类可捕量、天然鱼类资源、 物种多样性、种质资源产生了严重影响. 通过对下游渔业资源特征进行了描述, 结合当前重大水工建筑: 水电工程、调水工程、 航道工程、大桥工程及沙石开采工程, 介绍了长江水工工程的规模与现状, 探讨了不同工程对鱼类环境业已显现的影响, 以及对 渔业生态和资源的破坏作用, 剖析水工工程对渔业可能造成的潜在伤害. 同时就工程规划的设计理念、渔业生态的补偿措施提出 了建议, 指出渔业部门应尽的责任和义务, 提出了保护下游渔业资源和生态环境急待开展的科学研究任务.

关键词: 长江下游; 水工建筑; 渔业生态; 渔业资源; 影响; 补偿

\section{Stress of hydraulic engineering on fisheries in the lower reaches of the Yangtze River and compensation}

\author{
SHI Weigang ${ }^{1,2,3}$, ZHANG Minying ${ }^{1,2,3}$ LIU Kai $^{1,2,3}$, XU Dongpo $^{1,2,3}$ \& DUAN Jinrong ${ }^{1,2,3}$ \\ (1: Key Laboratory of Ecological Environment and Resources of Inland Fisheries, CAFS, Wuxi 214081, P.R.China) \\ (2: Freshwater Fisheries Research Center of the Chinese Academy of Fishery Sciences, Wuxi 214081, P.R.China) \\ (3: Lower Reaches of the Yangtze River Fishery Resources Station, Wuxi 214081, P.R.China)
}

Abstract: In the Low reaches of Yangtze River and the estuary region, there are rich fish species and high autochthonous species. The economic species that has an obvious fishing season characteristic almost distributes in this area, and the species number of the economic fish and fish catchability ranked first in the whole basin. In recent years the fishery ecological function has been weakened by many factors, such as river-lake disconnection, seawater intrusion, habitat fragmentation and hydrological changes due to the hydraulic engineering, and fish catchability, natural fishery resources, species diversity and idioplasm resources were also influenced seriously. In this paper, the development and status of hydraulic engineering and characteristics of fishery resources in the lower reaches of the Yangtze River have been introduced, basing on some important hydraulic engineering, such as waterpower projects, migration engineering, navigation engineering, bridge construction, and sand digging. Existing and latent impacts of hydraulic engineering on fishery resources and fishery ecological environment have also been discussed. Suggestions on design of hydraulic engineering and compensation methods for fishery ecology have been given. Responsibilities and obligations that the fishery department should take were pointed out. At last the urgent research tasks of protection of fisheries resources and environments in lower reaches of the Yangtze River were put forward.

Keywords: Lower reaches of the Yangtze River; hydraulic engineering; fishery ecology; fishery resource; effect; expiation

* 国家科技基础条件平台项目“长江中下游水产种质资源标准化整理、整合与共享”(2006DKA30470-003)和中央级基本科 研业务费专项基金(2007JBFA05、2007JBFB06、2007JBFB07)联合资助. 2008-05-05 收稿; 2008-07-31 收修改稿. 施炜 纲, 男, 1953 年生, 研究员; E-mail: shiwg@ffrc.cn. 
长江水系支流众多、湖泊密布，其中流域面积超过 $10000 \mathrm{~km}^{2}$ 的一级支流就有 26 条, 天然湖泊 4088 个, 面积 $24172 \mathrm{~km}^{2}$. 充足的水资源和优越的水文气候条件使长江成为典型的生态型河流, 稳定的自然环 境孕育了长江丰富的水生生物资源. 古往今来长江在维系生物多样性、自然生态平衡和国家生态安全方 面发挥着重要作用. 随着经济发展的需要，长江水资源功能的逐级开发，长江的原始生态正悄然地改变 着, 生物环境质量问题日益突出. 当前长江水域中生物多样性、生物资源总量、物种数量、生物链、能 流以及生物遗传基因等方面正面临巨大的考验. 已有关于工程对流域鱼类多样样影响的报道 ${ }^{[1]}$, 分析研 究了部分相关的影响因子. 但当前长江水工建筑的数量、规模、水资源利用特点及其与生态资源的关联 性的文献报道尚不多见，而国内外渔业研究人员对当前长江水工工程的现状、特点及工程背景的了解有 着较大需求. 本文就当前长江一些较大型工程对渔业资源的影响展开介绍与讨论, 期望有助于从事渔业 资源和生态工作不同层面之需求，以利于涉渔水域渔业权益的争取，监督水工工程在实现和谐友好的生 态环境建设中履行应尽的义务和责任.

\section{1 长江中下游原始河型与水工工程}

\section{1 中下游原始河型}

历史上稳定、延续不断的径流量、输沙量决定了长江相对平衡的生态环境，构成了长江包含分汉、顺 直微弯和曲流三种河型，中下游江段在来水来沙条件下构成了多鹅头状沙洲的地貌特征，沙洲通常为水生 动物、鱼类的栖息密集区、产卵场、索饵育肥场，也是洄游性动物、鱼类的瓶颈通道. 中游段：宜昌至湖口， 全长 $1015 \mathrm{~km}$, 长江出三峡即进人中游段, 河型以微弯型为主, 亦有少量分汉和曲流河型; 下游段: 湖口至 江阴, 全长 $696 \mathrm{~km}$, 河口段: 江阴至河口全长 $200 \mathrm{~km}$, 均为分汉河型. 在河床发育进程中分汉河型的演变过 程较为缓慢, 从地理学定义上认为, 长江是一条汉河型河流, 具有较高的生态稳定性 ${ }^{[2]}$. 近年来长江的年径 流量未见减少, 但输沙量却有减少的趋势, 潮滩向海淤涨明显减慢, 很大程度上是由于长江的输沙量减少 所致.

\section{2 长江水电工程}

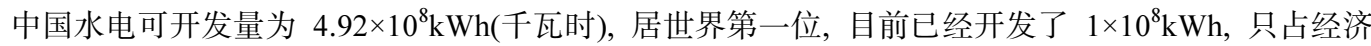
可开发量的约 $1 / 5$, 远远低于发达国家水平. 因此, 优先发展水电是中国能源战略的必然选择. 目前长江 流域已经建成的较大型水电设施约有 149 个, 正在建设的有 30 余个，规划之中的有 179 个，总计达到 338 个, 涉及到流域的干流及所有的支流. 据《中国国家地理》杂志不完全统计，仅以长江上游为例，金沙江 干流大于 $15 \times 10^{4} \mathrm{~kW}$ 的电站就规划了 21 座, 大渡河干流规划 17 级; 岷江上游 7 级, 而岷江的支流马边河 也规划 9 级电站开发, 岷江支流青衣江规划 18 级; 雅聋江干流规划 21 级, 雅聋江支流九龙河规划 6 级, 另一支流理塘河规划 11 级. 还有嘉陵江干流及各支流、乌江干流及各支流也有水电工程规划. 中国长江 三峡工程开发总公司在接受新华社记者专访时提出: “未来 20 年内, 中国将在长江干流以及㞾江、乌江、 雅聋江嘉陵江等支流上建设百座电站”; 中国能源规划提出, “大力发展水电, 开发西部水电资源, 建设 12 个水电基地”。继三峡工程后，于 2002 年，长江三峡开发总公司获国家授权先期开发金沙江下游河段的乌

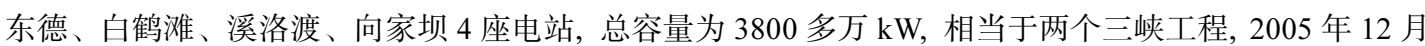
溪洛渡电站开工建设, 标志着金沙江干流水电梯级开发全面起动. 根据规划, 金沙江下游将建设 12 座梯 级电站, 装机总容量为 $5858 \mathrm{~kW}^{[3]}$.

\section{3 长江交通航运已建工程不完全统计}

截止 2006 年 12 月, 作为交通航运的大桥工程有 43 座：江苏省境内 6 座; 安徽省境内 3 座; 江西与 湖北省界之间 1 座; 湖北省境内 13 座; 四川省与重庆境内 20 座. 在建大桥工程不完全统计约 19 座; 拟 建大桥有 9 座; 大型航道工程不完全统计：上海河口区深水航道(已建)、长江 10 米深水航道向上延伸至 南京工程(已建). 崇明越江通道(在建)、武汉长江隧道(在建).

\section{4 长江干、支流挖沙工程}

长江河道采沙历史悠久，机械采沙于 20 世纪 80 年代后期形成大规模开采之势. 随着水工建筑的大 量兴建, 建筑沙石需求量大增, 在沙价上涨的利益驱动下, 采沙船蜂拥而至长江中下游河段, 形成滥采 
乱挖的混乱局面. 虽然长江采沙实行限采制度, 但偷采、乱挖现象仍然非常严重. 按水利部批复的《长江 中下游干流河道采沙规划报告》, 自湖北宜昌以下长 $1893 \mathrm{~km}$ 的长江中下游干流河道, 共设置 33 个可采 区，年度控制开采总量为 $3400 \times 10^{4} \mathrm{t}$, 控制采沙船数量 98 艘. 事实上长江现有采沙船只总数已处于失控状 态, 据不完全统计, 目前长江中下游大型采沙船有 1000 多艘, 而小型采沙船更是不计其数, 长江中下游 现有采沙船的年采沙能力已达数十亿吨. 同时大量的挖沙船进人支流和湖泊, 并有愈演愈烈之势, 以鄱 阳湖为例, 一吨成本不到四五元的江沙，运到上海、江苏即可卖到七八十元. 仅鄱阳湖区的一个县, 一年 拍卖采沙权就拍出了 1.2 亿元. 2006 年上半年长江水利委员会开始制订长江上游宜宾以下江段的采沙规 划, 整个长江干流的采沙都将开禁. 长江将面临更严峻的生态胁迫.

\section{2 长江下游渔业资源}

\section{1 长江下游拥有的国家级水生保护动物}

一级保护的有扬子鳄 Alligator sinensis; 白暨豚 Lipotes vexillifer; 中华鲟 Acipenser sinensis; 达氏鲟 Acipenserdabryanus; 白鲟 Psephurus gladiusg. 二级保护的有江豚 Neophocaena phocaenoides; 胭脂鱼 Myxocyprinus asiaticus; 松江鲈 Trachidermus fasciatus; 大鲵 Megalobatrachus davidianus; 花鳗 Anguilla marmorata. 其中扬子鳄 ${ }^{[4]}$ 、中华鲟 ${ }^{[5]}$ 、达氏鲟、江豚 ${ }^{[6]}$ 、胭脂鱼 ${ }^{[7-8]}$ 、松江鲇、大鲵 ${ }^{[9]}$ 人工繁殖已突破, 但 天然水域个体数量极少. 四川省宜宾珍稀水生动物研究所展开的达氏鲟子二代全人工繁殖于 2007 年获 成功. 上海水产大学潘连德教授开展的松江鲇鱼人繁, 2006 年首次育成万尾鱼苗.

\section{2 汛期尚存、凭证捕捞的长江经济鱼、蟹类}

目前长江下游尚存的专项捕捞品种仅剩风鲚 Coilia mystus(Linnaeus)、长领魰(刀鲚)Coilia ectenes、 中华线鳌蟹 Eriocheir sinensis(亲体)、鳗鳕Anguilla japonica(鳗苗)四个品种，是当前长江干流上唯一能形 成鱼汛且具捕捞价值品种，但这 4 个品种分布区逐年缩小、洄游路程缩减、可捕量急速递减. 河口区风 魰 1987-1989年年均捕捞量 2074.09t ${ }^{[10]}, 1990-1999$ 年年均捕捞量为 $1537.97 t ; 2000-2003$ 年降至 $793.89 \mathrm{t}^{[11]}$. 湖北武穴至江苏江阴江段上中华线鳌蟹 1986-1990 年年均捕拹量 183.306 $\mathrm{t}^{[12]}$ 、2001-2005 年捕拹量几乎 降为空白, 河口区中华线鳌蟹 1986-1990 年年均捕拹量 10.89t、2001-2005 年降至 2.92 $\mathrm{t}^{[13]}$. 安徽、江苏、 上海 1970-1974 年刀鲚年均捕捞量分别为 904t、1821t、265t, 1990-1999 年降至 382.5t、857.5t、(上海数 据缺), 2001-2005 年降至 138.19t、363.18t、127.14t $\mathrm{t}^{\mathrm{D}}$ ，中华线鳌蟹分布与洄游由湖北省退缩至江苏镇江以 东江段, 刀魰分布与洄游由洞庭湖退缩至安徽芜湖以东江段. 可见一些洄游性鱼、蟹几乎成了下游河口 定居性品种.

\section{3 捕捞夹带的具经济价值的鱼、虾、蟹类}

下游段捕捞作业中夹带的其它品种主要有四大家鱼、鲤、鲫、鳊(鳊、团头鲂、长春鳊、三角鲂)、 长吻鯔、黄颖(黄滪、江黄滪、岔尾滪、光泽黄滪)、鲌鱼(翘嘴红鲌、蒙古红鲌、青梢红鲌、红旗鲌)、鳎 鱼(三线舌鲳、窄体舌鲳)、鲖(圆吻鲖、细鳞斜领鲖、黄尾密鲖)、短领魰、鲻鱼、梭鱼、赤眼鳟、乌鳢、

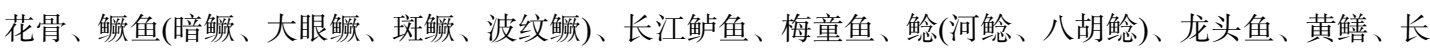
江铜鱼、圆口铜鱼、虾(秀丽白虾、青虾). 鲻、梭鱼原先仅出现在上海河口区, 但近年来随咸潮暗流不仅 出现在常熟、江阴江段, 最远在镇江江段也有发现.

\section{4 历史上经济价值较高并能构成捕捞汛期的鱼、虾资源品种}

有长江鲋鱼、东方鿵(暗纹、条纹、虫纹、弓斑)、长江银鱼(面丈鱼)、安氏白虾，历史上这些经济品 种均能构成每年一次汛期, 然而从 20 世纪 80 年代起相继消失了, 四大家鱼的苗汛也近乎消失, 20 世纪

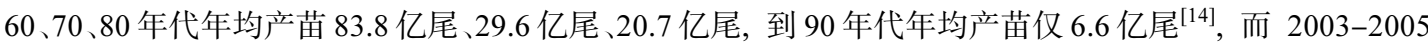
年监利监测断面家鱼鱼苗径流量分别为 4.06 亿尾、3.39 亿尾、1.05 亿尾，其中 2005 年鱼苗径流量是三 峡蓄水前本底值的 $4.2 \%$, 已达到历史上的最低年份 ${ }^{[15]}$.

(1) 长江渔业资源管理委员会. 长江刀魰综合调查报告. 2005 年. 


\section{3 水工建筑对长江渔业资源及生态的影响客观存在}

近年来长江的水工建设开发达到了前所未有的程度, 包括水电工程、港口建设、航道疏浚、航运、 建桥、筑坝、采沙作业等. 工程开发与建设在创造巨大经济效益的同时，也产生巨大的负面生态效应，造 成渔业生态环境恶化、水生生物栖息地被大量侵占、物种濒危程度加剧, 水生生物资源衰退速度加快, 种 质质量退化、资源总量锐减，渔业水域生态正面临着荒漠化的危险. 这种破坏往往是毁灭性和不可逆的， 会导致长江的渔业功能逐步丧失. 生态胁迫是资源下降的重要原因.

\section{1 坝水跌落及水温下降对鱼类资源的影响}

工程对鱼类适宜生存的水文条件的改变是显著的, 大坝泄出的冷水可削弱或消除坝下尾水中的温水 性渔业 ${ }^{[16]}$, 有报道指出美国科罗拉多河高坝泄出的冷水导致本地鱼类资源下降, 并演变为鲭属鱼类替代 了约 20 种本地土著种 ${ }^{[17]}$. 三峡库水跌落后, 坝下出现气体过饱和, 致使中华鲟鱼卵死亡, 鱼苗患气泡病 升至水面而死亡, 早在 1994 年阿根廷巴拉那河上的亚西累塔大坝就同样出现 $100 \mathrm{~km}$ 河段上大量死鱼事 件 ${ }^{[18]}$. 水库的调度运行使得洪峰削平, 导致长江 “四大家鱼” 产卵水文条件的变异, 严重影响到 “四大家 鱼” 的产卵繁殖. 坝下冷水对鱼类的产卵影响同样不可忽视, 胭脂鱼在每年 3-4 月产卵, 水温需求 $16.5-18^{\circ} \mathrm{C}$, 三峡大坝 $2-5$ 月下泄水温比建坝前降低 $2.8-4.4^{\circ} \mathrm{C}$, 将可能导致胭脂鱼产卵时间的推迟及性腺 的退化. 据长江下游渔业资源监测站监测报道自 2005 年三峡机组发电起, 在下游江段的铜鱼日趋稀少, 至 2007 年常熟以西江段的铜鱼在渔获中已基本消失, 分析认为: 铜鱼繁殖在宜昌、攀枝花等上游江段, 繁殖出的铜鱼江花经高坝水跌落后可能无法存活. 另外坝基消力池湍流、跌落时水压力变化、撞击、鱼 类自身渗透压的突然改变及受溢洪道表面擦伤，也会造成鱼类死亡，有实验证明当跌落速度超过 $16 \mathrm{~m} / \mathrm{s}$ 时, 这样的撞击会对鱼类的鰓、眼及内部器官造成严重伤害.

\section{2 水力涡轮机及水洜作用致使鱼类死亡}

水力浴轮机的运动部件的撞击, 瞬间的加速与减速以及压力和涡凹的突然变化, 均会对鱼类构成杀 伤. 尤其对一些长筒状体形的鱼类杀伤力更大, 有报道成鳗的死亡率比幼鲑高出 4-5 倍, 而一些小规模 电厂使用的小型涡轮机对成鳗的杀伤率会超过 $50 \%^{[19]}$, 侥幸逃出的伤残鱼类也极易受到攻击和被掠食, 包括这部分间接死亡，其死亡率可达 $30 \%$, 如大麻哈鱼 ${ }^{[20]}$. 而对于一些溯河、降河产卵的繁殖鱼类，由于 繁殖期鱼类游动灵敏性下降, 涡轮机对其的伤害则更为严重. 送调水过程中水㬌叶片也将构成对鱼类的 严重伤害, 同时由于瞬间抽提和跌落, 水压力的突变可导致鱼类渗透压失衡. 在以鳔壁血管进行气体交 换实现压力调节的闭鳔类鱼类(如鲇科鱼类)压力突变将导致鱼类后鳔破裂.

\section{3 工程施工对鱼类的影响}

水电工程、航道治理、港口建设对渔业生态的影响也是十分严重的，它包括工程建设期疏浚抛泥、 就地采石取沙、桥梁打桩、水下爆破、导堤建设等. 水下爆破、照明、粉尘、噪音会使鱼类产生回避或 伤害, 有报道高强度水下声能会对鱼类的听觉造成严重损害 ${ }^{[21]}$, 工程的施工, 使得局部水域悬浮物浓度 增加, 水色透明度下降, 抑制浮游植物繁殖生长, 从而导致水域初级生产力下降, 进而造成水域食物链 的变化. 工程施工还会使底栖生物赖以生存的栖息地遭受破坏, 在悬浮物增加以及在物理条件改变和饵 料生物减少的共同作用下, 对鱼卵的睬化率, 仔、幼鱼的生长和生存均会带来不利影响, 如: 长江口深水 航道建设对主航道附近区域的底栖生物就构成明显的不利影响 ${ }^{\mathbb{D} 22]}$, 致使底栖生物量损失数百吨, 水域 天然供饲能力下降，区域群落结构及生物多样性也将发生相应的变化. 如: 苏通大桥工程区是长江江豚、 白鲟、白暨豚等珍稀水生保护动物出没的深水水域, 频繁活动的船舶、施工废水、噪音、强光等不利因 素若不采取相应的管理和保护措施, 将会干扰保护动物的正常活动 2 .

\section{4 洄游距离导致生物群体的种质问题}

洄游通道长度对生物遗传质量的作用不可小视, 通道长度是洄游生物子代种质质量的天然生态保证, 洄游机制确保了对生物亲本进行自然淘汰与选择，但这一作用正随着建坝筑堤、造桥建港等人为活动而

(1) 上海环境科学研究院. 长江口深水航道治理工程二、三期工程环境影响报告书. 国环评证甲字第 1801, 2001: 5-14.

(2) 交通部公路科学研究所. 苏通长江公路大桥工程环境影响报告书. 国环评证甲字第 1016, 2003: 126. 
逐渐削弱，一些洄游性鱼类和水生动物受工程阻拦被迫改变洄游行程，有些物种被迫压缩在相对狭小的 水域中洄游与繁殖. 如中华线鳌蟹、刀鲚其洄游行程在 20 年内均缩短了一半以上，河口区凤鲚生境也日 趋狭窄. 从生物遗传性状上来讲, 未经笁选的亲本也加人了繁殖群体, 势必造成子一代遗传性状退化, 大自然对生物种群优胜劣汰的自然篮选作用的削弱, 其后果是十分严重的. 同时将造成苗种发生区狭小, 加剧了种间饵料资源和生境的竞争. 以历史中华线鳌蟹渔获规格与当前年份相比 ${ }^{[12]}, 1994-1999$ 年间江 阴至安庆江段中华线螯蟹平均体重、平均壳长、平均壳宽分别为 $132 \mathrm{~g} 、 58 \mathrm{~mm} 、 63 \mathrm{~mm}, 2000-2007$ 年为 $126 \mathrm{~g} 、 55 \mathrm{~mm} 、 59 \mathrm{~mm}$ ，分别下降了 $5.17 \% 、 6.35 \% 、 4.55 \%$ ，由此可见种质质量退化程度.

\section{5 洄游通道不畅导致鱼类数量下降}

每建一坝, 就渔业资源而言, 受危害最严重的就是洄游性的鱼类和野生动物. 20 世纪 80 年代初葛洲 坝建成时，由于中华鲟上溯产卵通道被阻断，生殖季节中华鲟试图越坝繁殖，在坝下成群跃起，被坝壁 撞得头破血流，场面极其惨烈. 万安大坝于 1990 年正式蓄水发电，切断了鲋鱼的洄游路线，使之无法上 溯至峡江上游产卵繁衍 ${ }^{[23]}$, 加快了这一稀少物种灭绝进程. 当前长江干流专业捕捞船大幅下降, 遗憾的 是洄游性鱼蟹类资源不仅没有上升, 相反仍呈持续下降的态势, 工程因素是重要影响因子之一. 以长江 刀鲚分布为例，70-80 年代东起河口，沿长江干流西至洞庭湖，另有两支，一支顺着京杭运河向北可至高 邮湖、骆马湖及洪泽湖，另一支沿东海沿岸路经启东、吕泗、弶港、射阳、赣榆，进人斗龙港、东台、新 洋河，抵达高邮湖、骆马湖及洪泽湖. 至 90 年代末，刀鲚分布区域缩减惊人，沿京杭运河和东海沿岸向北的 两组洄游鱼群完全绝迹. 湖北、湖南、江西三省长江江段上的刀魰也相继消失，江西的通江湖流中尚有部分 鲚鱼, 均为短额鲚, 九江、湖口尚有小部分刀鲚, 但数量十分稀少, 没有捕捞价值. 安徽省内的刀鲚已形 不成汛期, 江苏如南京、镇江也逐渐失去捕捞价值.

\section{6 工程沙石用量对渔业生态的影响}

水工工程大量建造, 使沙石用量规模急增, 为降低成本多数工程均采取就近取材的方案, 大量的 捕捞渔场遭到虫食，专业渔民失去捕捞场所或无法下水作业，同时它也严重破坏渔业资源，影响鱼类 的产卵、索饵、育肥，严重破坏鱼类的栖息环境和底栖生物的生存场所. 据江西省渔政部门监测, 在鄱 阳湖的吴城至湖口约 $100 \mathrm{~km}$ 的湖段因挖沙导致湖水长年处于高混浊状态, 湖水 $10^{\circ} \mathrm{C}$, 透明度只有 $25 \mathrm{~cm}$, 悬浮物高达 $0.7 \mathrm{~kg} / \mathrm{m}^{3}$, 长江与鄱阳湖间的洄游通道水体光合作用功能低下. 且部分水生生物亦因水中 悬浮物过多而窒息. 一条功率几千瓦的采沙船单次作业可在水底吸出直径 $60 \mathrm{~m}$ 的大坑, 功率更大的可 将水下深 $30 \mathrm{~m}$ 、直径 $100 \mathrm{~m}$ 范围内的沙石吸个精光. 严重的沙石开采给长江及通江湖泊渔业资源带来了 毁灭性的灾难.

\section{7 工程致使自然径流改变或消失带来的问题}

稳定的自然径流量是鱼类繁殖的基本生态要求，长江下游鱼类繁殖场受三峡等水工工程造成的不规 则的枯丰水影响，一些草滩产卵鱼类，所产卵会因水位下落而干枯死. 而丰水又使大量底层水草死烂， 不仅影响滩涂水草资源、滩涂环境，也使得草上产卵形鱼类失去产卵基床，直接影响鱼苗的发生量. 若南 水北调中线、东线调水工程竣工送水, 将使长江中、下游及河口区的枯水现象更趋严重, 南水北调东线 工程由于引水口比黄河处地面低 40 余米, 需设 13 个梯级抽水泵站, 逐级泵水向京、津地区送水, 总扬程 $65 \mathrm{~m}$, 一期工程多年平均抽江水量 $89 \times 10^{8} \mathrm{~m}^{3}$, 调水流量约占长江大通站多年平均流量的 $1.74 \%$. 泵水将构 成对长江鱼类苗种的杀伤，65m 的总扬程使得大量鱼苗被抽提上抛，一些借助视觉器官判定食物方位的 鱼类, 进人涵洞后, 其摄食功能将丧失, 因为光照在其受食过程中的意义重大, 光照时间的长短以一定 的方式影响着食物保障 ${ }^{[24]}$. 同时由于随洜级站的提高, 水体浮游生物逐渐下降, 幼鱼饵料保证也会发生 困难. 由于受泵站阻隔，洄游性品种被逐级抽提后将无法再返回. 泄水量的削减将使江水流速减慢，导 致江水含沙量下降，透明度增大将导致光合作用水平及水域生产力结构的改变. 同时大坝拦截作用也将 导致下游三角洲和河口区沉积物减少 ${ }^{[25-26]}$. 造成初级生产力和饵料资源的短缺.

\section{8 工程导致河口区海水的入侵问题}

当前河口枯水期形成的海淡水交汇锋面已直接指向汶河以西的南通、常熟、江阴等江段. 严重的盐 水人侵已成为长江口主要的水资源利用障碍, 据吴淞、高桥、堡镇等月氯化物含量统计, 长江口北支、 
北港和南北槽等水域, 大于 $250 \mathrm{mg} / \mathrm{L}$ 氯化物含量的不可取水天数已达 $45 \mathrm{~d}$ 左右 ${ }^{[27]}$, 但海水人侵在今后若 干年还将加剧. 根据南水北调东线工程环境影响报告书概要指出: “南水北调东线工程调水将会对长江口 枯水期盐水人侵带来一定负面影响, 特别是枯水年的枯水期. 但三峡工程运行后, 1-4 月会使大通站流量 增加 $1000-2000 \mathrm{~m}^{3} / \mathrm{s}$. 若通过三峡工程的合理调度, 开展封堵北支工程, 则南水北调工程对长江口盐水入 侵产生的负面影响将得到缓解甚至抵消”. 报告书中 “开展封堵北支工程” 是值得商榷的, 河口北支洄游 通道功能将彻底消失, 长江口北支原本受淤浅影响涌潮 ${ }^{[28]}$ 正日趋发展和增强, 一旦封堵北支则涌浪的势 能又向何处宣泄. 而报告书中 “若通过三峡工程的合理调度则南水北调工程对长江口盐水入侵产生的负 面影响将得到缓解甚至抵消”, 还是较车强. 众所周知电站须保持一定跌落水高度来满足发电需要, 电站 的蓄、泄水调度主要取决于坝上库水位高度. 因此, 这样的设想, 是否能实现? 一个偌大工程所产生的负 面影响寄希望另一工程的合理调度来解决, 其合理性和可行性也是值得商榷的. 南水北调东线工程一旦 竣工, 大量的淡水被送出, 使得人海水量减小、下游水域面积缩减 ${ }^{[29]}$, 河口区海水的侵人更趋严重. 当盐 度超出河口区生物耐受极限时, 生物区系重组将不可避免. 咸淡水洄游性鱼类的洄游路线和洄游规律将 随之改变，同时河口段水生生物的索饵场、产卵场、江滩植被也可能随之动迁、更替. 工程致使鱼类区 系的更替演变、生物多样性的变动、河口中华鲟保护区的安全、渔民捕捞作业区动迁等问题将在若干年 后逐步现显.

\section{9 工程致使鱼类生存空间减少, 漫长的工期对洄游性生物构成世代缺失}

工程营运期的影响除了航行船舶的含油污水、生活污水、生活垃圾增加的危害外，还挤占了水生生 物生存空间, 河口区水工工程导致了凤鲚生存空间狭小，凤鲚的可捕水域也逐年趋小. 加之频繁的工程 船只运输, 使鱼类赖以生存的自然空间大大缩水, 在狭小的生境中螺旋桨击毕珍稀野生动物的事件时有 发生. 如 2005 年 7 月, 长江南通段一条中华鲍, 被螺旋桨切去尾部, 而这条中华鲟是国内已知的最大个 体. 漫长的工程施工期对洄游性生物构成世代缺失: 施工期对局部水域生态的影响导致洄游通道出现断 裂, 一些工程施工期短则 1-2 年, 长则 7-8 年, 甚至十几年, 这对一些洄游性生物来讲是致命的, 这些生 物需要降河或上溯至繁殖地, 连续多年的通道阻隔, 会造成该物种连续几个世代的补充群体数量稀缺. 苏通大桥的施工期为 7-8 年, 三峡工程建设工期为 17 年, 南水北调工程仅东线一期 5 年、中线一期工程 7 年, 项目总建设时间约为 40-50 年, 因而在施工期注重洄游通道的畅通, 最大限度地防止通道堵塞有助 于洄游性生物的繁衍.

\subsection{0 生境的片断化对生物多样性的影响}

河流生态系统的存在和发展依赖碳、氮、磷等生源要素的可获得性，而生物作用过程又是控制或影 响河流、水库系统内生源物质循环更新的重要环节 ${ }^{[30]}$. 生境的片断化使稳定的群落多样性变得单一和脆 弱, 生物多样性不仅受物种数丰富程度的影响, 还受单一物种内部基因多样性的影响, 这是物种自身稳 定延续的基础条件，由于生境割裂造成种内基因无法充分交换，造成环境的抗逆能力下降. 如长江所产 刀魰以肉质细嫩、肥㖑著称，而太湖的刀鲚由于生境割裂与长江通道不畅，形成定居型种群，虽然太湖拥 有庞大的刀鲚种群, 但因与长江刀魰基因交换困难, 其肉质和含脂量远不及长江种, 这就是生境的片断 化导致同种生物无法交换基因的典型例子. 当前一些物种的人工繁殖虽已突破，但长期养殖条件下形成 的品种优良性状下降却无法回避, 得不到天然野生物种基因的交换, 鱼品质量下降也就成了自然, 因此, 长江天然原种场及种质基因库的作用是无法替代的，保持生境的连续化是十分重要的.

\subsection{1 江河的割裂使生命物质传递受阻}

河流被截断后形成了河流的非连续性特征, 改变了连续性河流的规律. 它不仅影响大坝上下游河流 地貌学特征, 同时也造成自然水文周期的人工化, 目前大坝环境影响评价往往是从个别学科或局部功能 的需要出发, 孤立地研究水库淹没区的濒危或特殊动植物的保护问题, 或者孤立地研究对于水质的影响 问题等, 有些水工工程的环评报告中会有这样的表述: “工程峻工后, 年内下泄水总量不变, 防洪能力将 大幅提高”, 但这并不意味对生态没有影响. 河流生态系统是一种开放的、流动的生态系统, 其连续性不 仅指一条河流的水文学意义上的连续性, 同时也是对于生物群落营养物质输移的连续性 ${ }^{[31-33]}$. 此外, 还 包括生物种内、种间信息传递的连续性，这点至关重要却又恰恰被人们所忽略. 洪水周期变化对于聚集 
在河流周围的生物是一种特殊的信号，这些生物依据这种信号进行繁殖、产卵和迁徙，也就是说河流还 肩负着传递生命信息的任务. 河流的连续性，不仅包括水流的水文连续性，还包括营养物质输移的连续 性、生物群落的连续性和信息流的连续性.

\subsection{2 工程规划、遗留工程或二次施工导致对生态的二次影响}

以葛洲坝水利工程为例, 20 世纪 80 年代初建成, 当下泄流量大于 $25000 \mathrm{~m}^{3} / \mathrm{s}$ 时, 下游航道及下闸首就出 现能量较大的横向涌浪, 导致上行船只难以顺利过闸, 迫使大江船闸停止通航. 建坝 20 年后葛洲坝水利枢 纽下游河势调整工程开工, 采用在江心滩上修建 $900 \mathrm{~m}$ 江心堤和在二江适当进行水下开挖的综合治理方案 使电站尾水出流顺畅，以达到下泄流量等于 $30000 \mathrm{~m}^{3} / \mathrm{s}$ 时的安全通航能力，而施工江段恰位于长江湖北宜昌 中华鲟自然保护区. 有研究表明自葛洲坝截流后该区域中华鲟的自然繁殖并未停止过 ${ }^{[34]}$, 但二次施工影响 涉及范围 $5 \mathrm{~km}^{2}$, 河势调整工程将改变该江段水流的流速, 二江下槽开挖将改变其水下地形, 直接扰动或破 坏中华鲟坝下产卵交配区，可能严重影响珍稀濒危水生野生动物中华鲟的栖息与繁殖 ${ }^{\circledR}$.

\section{4 工程生态补偿措施}

世界上不存在百利而无一害的工程技术，权衡利弊，趋利避害是辩证的思维方法. 尽管在国际有部 分学者反对建坝甚至提出拆坝的呼吁 ${ }^{[35]}$, 有学者认为筑坝是河流生态环境受人为影响最显著、最广泛、 最严重的事件之一 ${ }^{[36]}$ ，近年来国际反对建坝的声浪高涨，在国内外一些关于能源政策的报告中，水电作 为可再生清洁能源正在消失. 也有学者提出以风力、核能取代水力发电的计划, 但我国毕竟是世界能源 紧缺国之一，而水电资源却十分丰富，鉴于水电资源的可循环开发及不产生废气、废物之优势，其在我国 经济建设中满足防洪、发电、灌溉、供水等方面的作用是无容置疑的. 大坝对于河流生态系统的负面影 响, 可以通过工程措施、生物措施和管理措施在一定程度上避免、减轻或补偿.

\section{1 工程措施}

4.1.1 自然生态多样性补救 工程应最大限度兼顾河流形态的多样性、断面形状的多样性和蜿蜒性,保持江 河原有的自然生态, 尽可能将对生态、资源的影响降至最低, 为水生植物和动物提供栖息条件. 必要的情 况下应由工程专款建造过鱼设施. 虽然在我国已经有一些溯河洄游的过鱼设施，设施的设计在近几年已 有很大的改进, 但大多数设施的成功率并不令人乐观 ${ }^{[37-38]}$, 在国际上有一些过鱼设施如: 水池型鱼道 ${ }^{[39]}$ 、 丹尼尔鱼道 ${ }^{[40-43]}$ 、水渠式鱼道 ${ }^{[44]}$ 、升鱼机 ${ }^{[45]}$ 、鱼闸 ${ }^{[46]}$ 、集运设施 ${ }^{[46]}$ 等均有成功的范例可借鉴.

4.1.2 坚持工程各期评估做好补偿费用预算 河流生态系统演替是一个漫长的过程 ${ }^{[7]}$, 工程影响也是漫长 逐步显现的过程，不仅需要坚持开展施工期监测与评估，还应定期开展工程运行期、退出期的生态监测 与评价，建立确保生态系统健康的水资源调度方式，这些在工程建设报告中应有明确的量化指标. 在工 程施工期中给予充足的生态补偿费预算, 在工程运行受益期内也应从运行利润中明确一定比例的生态补 偿费，以便进行长期的生物、生态补救，如保护区建设、增殖放流、生物专项救护及相关的受工程影响 的专项研究, 水工工程老年化对生态的影响也应予以重视.

4.1 .3 提供全方位生态补偿 除生物资源直接补偿外, 生态修复还应包括江河连续性、河床、河态、水势 的补偿修复, 应从江河水文、气象、化学、物理等多层面出发来考虑水域的初级生产力、水生植物、水 生动物、生物多样性、自然景观及湿地功能等的补偿修复.

\section{2 非工程措施}

4.2.1 建立健全法律法规体系建设 有关部门应着手鱼类洄游通道恢复方面的法律法规制定, 坚持水工工 程环评信息公示化，包括参评单位、参评专家、工程背景、工程规划、环评结论等信息的公示制度. 逐 步形成完善的鱼类洄游通道法律法规体系.

4.2.2 形成社会合力开展生态保护 生态修复工程是社会工程, 应提高生态保护的全民意识, 自觉参和履 行应尽的义务与责任. 除工程业主外，社会、公众、流域各方政府、企、事业单位均应从自身行业领域 的优势出发，在专业技术、资金筹措等方面献计献策，形成社会合力. 除国家政府专项拨款外，一些国际

(1) 长江水资源保护科学研究所. 葛洲坝水利枢纽下游河势调整工程环境影响报告书. 国环评证甲字第 2602, 2005: 7. 
基金、生态保护组织、民间组织、慈善机构也不失为有效的资金筹措渠道.

4.2.3 加强渔业部门能力建设积极开展生态、资源救护作为生态与资源受影响较大的渔业部门，应整合 自身的管理能力、科研力量, 不断提高渔业管理能力、人员素质及科研能力, 在活体养护、人繁研究、 增殖放流、异地迁移、人工湿地、禁渔制度、保护区建设及对资源的合理利用等方面积极开展生态、资 源自救, 尽可能降低损失, 促进渔业生态和资源的可持续发展.

4.2.4 重视科学调查加大科学研究力度 工程对渔业环境和资源的影响已形成了社会共识, 但工程论证阶 段真正涉及渔业生态在时、空、量尺度下的具体量值时, 现有渔业资料常显得较为苍白, 不仅较难作为 工程环评的界定依据, 更重要的是影响了渔业自身日后发展, 一旦影响显现后或获得工程方补偿后再加 补救, 往往是事倍功半. 因此, 渔业部门应加大对水域生态、资源的监测与研究力度, 构建系统、规范、 科学的本底资料, 以防患于未然. 近期急待开展的科研任务: 重要经济鱼类的资源及生态需求、海水人侵 与渔业生态及资源的相关性、洄游性鱼类的繁殖生物学及洄游特征、江段重要经济鱼类、珍稀动物空间 分布格局、江段鱼类区系、生物多样与环境生态 的联动效应、稀缺物种遗传性状、种质基因保存、 流域渔业 GIS 系统等研究均将有助于水工工程的 环评、规划、施工和营运.

\section{3 关于下游经济鱼蟹类捕捞及保护建议}

依据长江下游渔业资源监测站对主要经济鱼 蟹的捕捞量统计, 刀鲚产量急速下滑, 尤其在刀 鲚人工繁殖尚未突破的当前, 保护长江刀魰资源 的任务显得相当紧迫(图 1, 图 2). 建议: 东起上 海河口区，西至湖北武穴江段，每年 2-6 月全面 实施刀鲚休渔制度, 施行期 3-5 年, 同步开展资 源跟踪调研, 届时依据刀魰资源再决定继续禁捕 或实行限额捕捞制度.

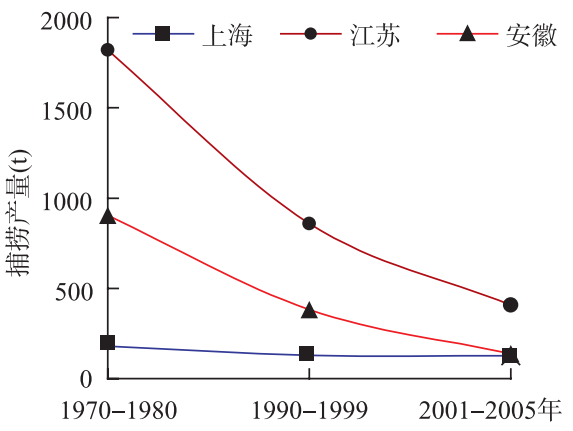

图 1 长江下游及河口区刀鲚历史年平均捕捞产量

Fig.1 Average annual catch of estuarine tapertail anchovy in the low of the Yangtze River and the estuary region in the history
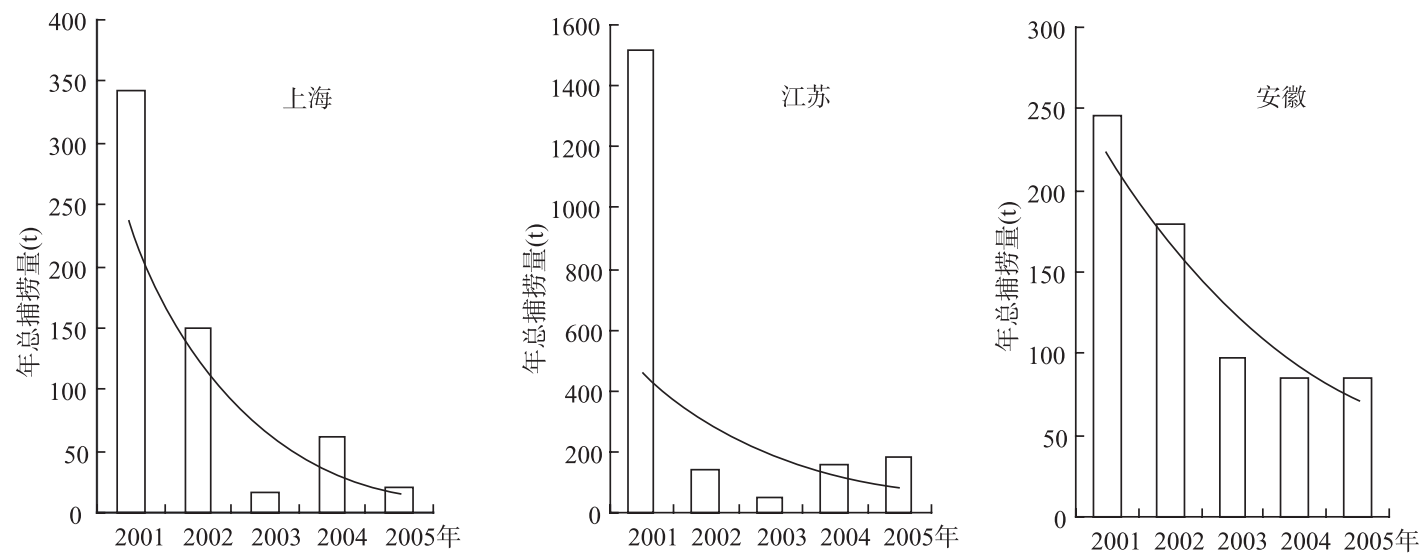

图 2 长江下游及河口区近年刀鲚年总渔获量

Fig.2 Total annual catch of estuarine tapertail anchovy in the low of the Yangtze River and the estuary region in recent years

河口区亲蟹捕捞量从 1989 年起持续下降(图 3a), 河口区近年平均亲蟹捕捞量低于 $5 \mathrm{t}$, 还不足当前庞 大养殖产量的零头，因此在天然亲蟹资源稀缺的当前，在河蟹天然种质资源最后一块发源地一一河口区 继续开展亲蟹捕捞是十分不明智的. 建议长江中下游干流全流域实施禁捕, 以保护长江中华线鳌蟹这一 
优质种质资源. 2005 年产量的突然上升，主要是由于 2003-2004 两年河口区大规模放流河蟹所致.
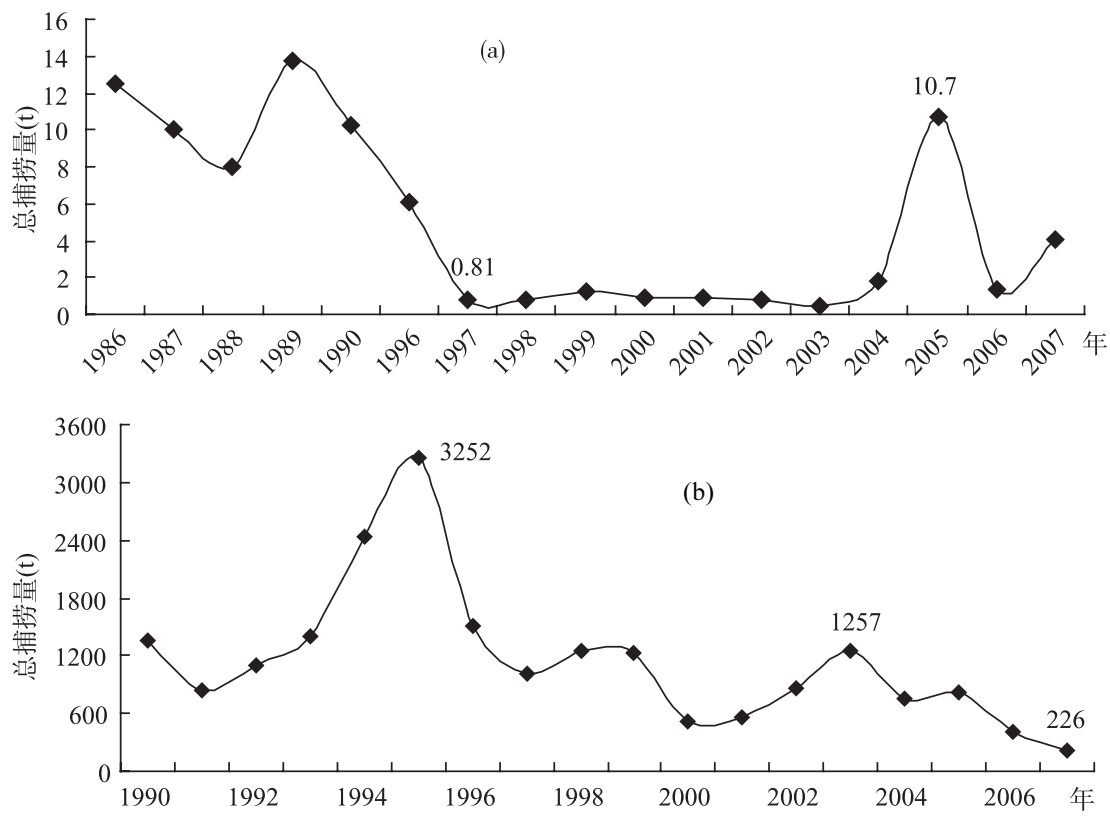

图 3 长江口中华线鳌蟹亲体(a)和凤鲚(b)年总渔获量

(1991-1995 年监测中断, 中华线鳌蟹数据缺失)

Fig.3 Total annual catch of matured mitten crab(a) and tapertail anchovy(b) in the estuary region of the Yangtze River

自 1990 起大部分年份的凤鲚捕捞量均在 500-1500t 徘徊，总体上略有下降，但与河蟹、刀鲚相比还 是相对较稳定, 这是由于凤鲚为近海至河口洄游性物种, 相对河蟹、刀魰而言, 受整个长江中下游生态环 境质量的制约影响相对较小. 但自 2003 年起可见捕捞量有快速下降的趋势(图 3b), 2007 年捕捞总量仅为 $226 \mathrm{t}$ ，一般来讲捕捞总量可间接反映资源密度状况，但凤鲚捕捞量在某种程度上并不一定能真实反映其 资源密度，其原因是：近年上海河口区的深水航道、越江隧道工程等大量挤占了凤鲚生存空间，这对凤鲚 资源的再生是不利的，但另一方面由于受工程挤占，使捕捞场地变得狭窄，从而导致捕捞总产下降，这 对保护凤魰资源, 缩减风魰捕捞能力来讲又是有利的. 因此建议: 应密切关注凤魰捕捞量与资源密度的 趋向, 加强科学调查研究的力度, 每年动态制定专项捕捞证的发放数, 确保凤鲚资源的可持续利用.

\section{5 结语}

长江是一开放性河流, 水工工程对生物资源与生态环境的影响仅是多种影响因素之一, 流域还受到 水域污染、渔业行为、河流发育等多种因素的影响，因此要定量界定水工工程对长江生态和资源的影响 是很难做到的, 但水工建筑对渔业生态的胁迫又是无法回避的客观事实. 在我国水利水电建设中, 需要 正视这种负面影响并主动研究对河流生态系统的补偿技术、政策和管理措施等问题，探索与生态环境友 好的水工工程建设新模式.

致谢: 本文中历年渔业数据的调查得益于长江渔业资源管理委员会、上海市、江苏省、安徽省、江西省 等各级渔政管理部门的协调与帮助, 在此一并致谢!

\section{6 参考文献}

[1] 黄 亮. 水工建筑对长江流域鱼类生物多样的影响及其对策. 湖泊科学, 2006, 18(5): 551-556. 
[2] 中国科学院地理研究所, 中国水利水电研究所, 长江航道局规划设计研究所. 长江中下游河道特性及其演变. 北京: 科 学出版社, 1985: 255.

[3] 新华社. 中国将在长江干流以及峎江等支流建百座电站. 水电厂自动化, 2006, (2): 2.

[4] 汪仁平, 夏同胜. 人工条件下越冬扬子䱏的繁殖. 动物学杂志, 2005, 40(4): 92-95.

[5] 刘鉴毅, 危起伟, 杜 浩等. 中华鲄人工繁殖关键技术的改进效果研究. 经济动物学报, 2006, 10(2): 96-100.

[6] 郝玉江, 王 丁, 张先锋. 长江江豚繁殖生物学研究概述. 兽类学报, 2006, 26(2): 91-200.

[7] 李家明, 王 庆. 长江胭脂鱼人工繁殖技术总结. 水产养殖, 2007, 28(3): 15-17.

[8] 胡隐昌. 胭脂鱼的人工繁殖技术. 珠江水产, 2001, 37(3): 20-26.

[9] 刘鉴毅, 谭永安, 庄 平. 中国大鲵子二代制种技术的研究. 经济动物学报, 2004, 8(3): 167-170.

[10] 施炜纲, 王＼cjkstart博. 长江河口区凤鲚的资源现状. 水生生物学报, 2002, 26(6): 648-653.

[11] 刘 凯, 张敏莹, 徐东坡等. 长江口凤鲛资源变动及最大持续产量研究. 上海水产大学学报, 2004, 13(4): 298-303.

[12] 施炜纲, 周 昕. 长江中下游中华线鳌蟹亲体资源动态研究. 水生生物学报, 2002, 26(6): 641-647.

[13] 刘 凯, 段金荣，徐东坡等. 长江口中华线鳌蟹亲体捕捞量现状及波动原因. 湖泊科学, 2007, 19(2): 212-217.

[14] 陈大庆, 段辛斌, 刘绍平等. 长江渔业资源变动和管理对策. 水生生物学报, 2002, 26(6): 686-690.

[15] 刘绍平, 陈大庆，段辛斌等. 长江中上游四大家鱼资源监测与渔业管理. 长江流域资源与环境, 2004, 13(2): 183-186.

[16] Pasch RW, Hackney PA. Ecology of paddlefish in old Hickory Reservoir, Tennessee, with emphasis on first-year life history. Transactions of the American Fisheries Society, 1980, 109(2): 157-167.

[17] Holden PB, Stalnaker CB. Distribution and abundance of mainstream fishes of the middle and upper Colorado River basins Transactions of the American Fisheries Society, 1975, 104(2): 217-231.

[18] Bechara JA, Domitrovic HA, Quintana CF. The effect of gas supersaturation on fish health below Yacyreta dam(Parana River,Argentina). In: Leclerc M, Capra H, Valentin S eds. Second international symposium on habitat hydraulics. Canada: INRS Publisher, 1996

[19] Hadderingh RH, Bakker HD. Fish mortality due to passage though hydroelectric power stations on the Meuse and Vecht rivers. In: Jungwirth M, Schmutz ND, Weiss S eds. Fish migration and fish bypasses. Oxford, United Kingdom: Blackwell Science Ltd Publisher, 1998.

[20] Raymond HI. Effects on dams and impoundments on the migration rate of Juvenile Chinook Salmon and Steelhead Trout from the Snake River, 1966-1975. Transactions of the American Fisheries Society, 1979, 108(6): 509-29.

[21] McCauley RD, Fewtrell J, Popper AN. High intensity anthropogenic sound damages fish ears. Journal of the Acoustical Society of America, 2003, 113(1): 638-642.

[22] Pringle CM, Freeman MC, Freeman BJ. Regional effects of hydrological alterations on riverine macrobiota in the New World Tropical temperate comparisons. Bioscience, 2000, 50(9): 807-823.

[23] 贾敬德. 淡水渔业环境现状及保护对策. 淡水渔业, 2004, 34(5): 59-61.

[24] 尼科里斯基 $\Gamma$ B. 鱼类种群变动理论. 北京: 农业出版社, 1982: 58.

[25] Mccully P. Silenced river. London: Zed Books Ltd, 1996: 100-130.

[26] 祁继英, 阮晓红. 大坝对河流生态系统的环境影响分析. 河海大学学报(自然科学版), 2005, 33(1): 37-40.

[27] 阮仁良, 韩昌来. 长江流域社会经济发展对长江口水域功能开发的影响. 上海水务, 2004, 20(1): 33-37.

[28] 陈沈良, 陈吉余, 谷国传. 长江口北支的涌潮及其对河口的影响. 华东师范大学学报(自然科学版), 2003, (2): 74-80.

[29] Rosenberg DM, Mccully P, Pringle CM. Globa1-scale environmental effects of hydrological alterations. Bioscience, 2000, 50(9): 746-751.

[30] 毛战坡, 王雨春, 彭文启. 筑坝对河流生态系统影响研究进展. 水科学进展, 2005, 16(1): 134-140.

[31] Wootton JT, Parker ME. Effects of disturbance on river food webs. Science, 1996, 273(5281): 1558-1561.

[32] Vannote RL. The river continuum concept. Can J Fish Aquat Sci, 1980, 37(1): 130-137.

[33] 董哲仁. 筑坝河流的生态补偿. 中国工程科学, 2006, 8(1): 5-10.

[34] 危起伟, 陈细华, 杨德国等. 葛洲坝截流 24 年来中华鲟产卵群体结构的变化. 中国水产科学, 2005, 12(4): 452-457. 
[35] Hart DD, Poff NL. A special section on dam removal and river restoration. BioScience, 2002, 52(8): 653-747.

[36] Petts GE. Impounded rivers: perspectives for ecological management. Journal of the North American, 1986, 5(1): 86-87.

[37] Marmulla MR. Improved fish passage can contribute to a better protection of the living aquatic resources in the Yangtze. The Yangtze River Forum of Organism Resources Conservation. Speech \& communication materials, Shanghai, China, 2007: 43-48.

[38] 王兴勇, 郭 军. 国内外鱼道研究与建设. 中国水利水电科学研究院院报, 2005, 3(3): 222-228.

[39] Travade FM, Larinier S, Boyer-Bernard et al. Perforance of four fish pass installations recently built in France. In: Jungwirth M, Schmutz ND, Weiss S eds. Fish migration and fish bypasses. Oxford, United Kingdom: Blackwell Science Ltd, 1998

[40] Rajaratnam N, Katopodis C. Hydraulics of Denil fishways. Journal of Hydraulic Engineering, 1984, 110(9): 1219-1233.

[41] Rajaratnam N, Katopodis C, Solanki S. New designs for vertical slot fishways. Canadian Journal of Civil Engineering, 1992, 19(3): $402-414$

[42] Slatick E, Basham LR. The effect of Denil fishway length on passage of some nonsalmonid fishes. Marine Fisheries Review, 1985, 47(1): 83-85.

[43] Laine A, Kamula R, Hooli J. Fish and lamprey passage in a combined Denil and vertical slot fishway. Fisheries Management and Ecology, 1998, 5(1): 31-44

[44] Parasiewicz P, Eberstaller J, Weiss S. Conceptual guidelines for natural-like bypass channels. In: Jungwirth M, Schmutz S, Weiss S eds. Fish migration and fish bypasses. Oxford, United Kingdom: Blackwell Science Ltd, 1998.

[45] Travade F, Larinier M. Ecluses et ascenseurs á Poissons. Bulleting Francais de Pêche et Pisciculture, 1992, 326-327: 95-110.

[46] Clay CH. Design of fishway and other fish facikities. Florida, USA: CRC Press Publisher, 1995.

[47] 董哲仁. 国外河流健康评估技术. 水利水电技术, 2005, 36(11): 15-19. 